\title{
Potential role of acrylic acid in bacterioplankton communities in the sea
}

\author{
Doris M. Slezak ${ }^{1}$, Stasa Puskaric ${ }^{2}$, Gerhard J. Herndl ${ }^{1, *}$ \\ ${ }^{1}$ Department of Marine Biology, Institute of Zoology, University of Vienna, Althanstr. 14, A-1090 Vienna, Austria \\ 2 'Ruder Boskovic' Institute, Center for Marine Research Rovinj, Croatia
}

\begin{abstract}
Since the early work of Sieburth (1960; Science 132: 676-677) acrylic acid has frequently been mentioned as inhibiting bacterial growth in the sea, although this has not been tested thoroughly. Recent focus on dimethylsulfoniopropionate (DMSP) and its cleavage into equimolar concentrations of dimethylsulfide (DMS) and acrylic acid has led to increased speculation that acrylic acid may retard bacterial growth. In order to test the role of acrylic acid in controlling bacterial metabolism we performed experiments with bacterioplankton originating from the upper mixed layer of the Adriatic Sea. In short-term experiments $(20 \mathrm{~min}$ incubation period) leucine as well as thymidine incorporation into bacteria were reduced by $\geq 50 \%$ at acrylic acid concentrations $\geq 1 \mathrm{mM}$ while in long-term incubations of seawater cultures ( 24 to $110 \mathrm{~h}$ ) bacterial activity was retarded at acrylic acid concentrations $>10 \mu \mathrm{M}$. In order to test potential effects of $\mathrm{pH}$ deviations, experiments with seawater cultures amended with $10 \mathrm{mM}$ acrylic acid and adjusted $\mathrm{pH}(8.0)$ were performed, indicating that in $\mathrm{pH}$-adjusted cultures bacterial production is reduced to ca $40 \%$ of the production rate in unamended cultures while bacterial production in cultures with unadjusted $\mathrm{pH}$ is reduced to ca $2 \%$. Although few data are available, we assume that acrylic acid concentrations in natural waters are similar to those of DMS (in the nM range). If this is true, then bacterioplankton will rarely experience growth inhibition by acrylic acid in the environment. Only under specific conditions when phytoplankton forms aggregates, e.g. marine snow or Phaeocystis colonies, could acrylic acid play a role in reducing bacterial metabolism.
\end{abstract}

KEY WORDS: Bacteria Acrylic acid - Metabolism

\section{INTRODUCTION}

Dimethylsulfide (DMS) in marine environments has been recognized as a potentially important substance in the global sulfur cycle (Barnard et al. 1982, Andreae 1990, Erickson et al. 1990, Malin et al. 1992). This gas has been suggested to influence the global climate due to its potential role in stratospheric cloud formation (Bates et al. 1987a, Charlson et al. 1987). DMS may also contribute to the formation of acid rain when it becomes oxidized and forms sulfate aerosols in the atmosphere (Charlson \& Rodhe 1982). Thus, although originating from the marine environment, DMS influences the composition of the atmosphere as well as life in terrestrial systems. DMS is enzymatically cleaved from dimethylsulfoniopropionate (DMSP) (Cantoni \&

\footnotetext{
- Addressee for correspondence
}

Anderson 1956). DMSP is produced by marine algae and most likely acts as an osmoregulator in cells (Vairavamurthy et al. 1985, Dickson \& Kirst 1986). Among the phytoplankton organisms producing large amounts of DMSP are dinoflagellates and prymnesiophytes (Keller et al. 1989a, b).

Besides DMS, acrylic acid is produced in equimolar concentrations from DMSP; this reaction pathway is mediated by microbial enzymes (Cantoni \& Anderson 1956). Little is known, however, on the rates and degradation pathways of DMS and acrylic acid in seawater (Kiene \& Bates 1990). Brimblecombe \& Shooter (1986) have shown that DMS is photo-oxidized in sunlight at about the same rates as DMS is lost to the atmosphere via the air-seawater interface. While DMS concentrations and production rates have been measured for a variety of environments (Holligan et al. 1987, Turner et al. 1988, Cooper \& Matrai 1989, Fogel- 
qvist 1991), acrylic acid has so far received little attention. The most frequently cited paper dealing with the influence of acrylic acid on marine life is that by Sieburth (1960). In his study, several bacterial species were tested using plating techniques for their ability to grow on media with different concentrations of acrylic acid. Nine out of 12 bacterial strains tested were growth-inhibited at acrylic acid concentrations in the media of $\geq 5 \mathrm{mg} \mathrm{ml}^{-1}$ (equivalent to a concentration of $\geq 69 \mathrm{mM}$ ); 2 of the other 3 strains tested were not inhibited even at acrylic acid concentrations of $>50 \mathrm{mg}$ $\mathrm{ml}^{-1}$ (or $>690 \mathrm{mM}$ ). The lowest concentration of acrylic acid provoking growth inhibition was detected for Pasteurella multocida $\left(0.025 \mathrm{mg} \mathrm{ml}^{-1}\right.$ or $\left.347 \mu \mathrm{M}\right)$. Obviously, there are large variations among different bacterial strains in their sensitivity to acrylic acid. The concentrations used by Sieburth (1960), however, were about 3 orders of magnitude higher than one would expect in the euphotic zone of the sea based on the concentrations of DMSP and DMS and, moreover, the $\mathrm{pH}$ might have been significantly lower than in original seawater. Davidson \& Marchant (1987) found inhibitory effects of acrylic acid on bacterial abundance; however, they presented neither data on acrylic acid concentrations nor data on bacterial metabolism.

The purpose of this study was to follow growth of bacterial communities in seawater amended with different concentrations of acrylic acid and to differentiate the effects of acrylic acid and $\mathrm{pH}$ on bacterial growth. The rationale was based on the finding that those phytoplankton species which exhibit the highest rates of DMSP production are also those which respond most to eutrophication (Keller et al. 1989b); especially dinoflagellates produce copious amounts of DMSP. If we assume that high concentrations of DMSP ultimately lead to high concentrations of acrylic acid too, we might expect retarded bacterial growth in eutrophic waters due to the presence of elevated concentrations of acrylic acid. Retarded bacterial growth rates in eutrophic waters might then be responsible for the observed differences in the biomass ratio between phytoplankton and bacteria between oligo- and eutrophic waters (Dortch \& Packard 1989, Fuhrman et al. 1989, Cho \& Azam 1990). Frequently, bacterial growth rates decline from oligotrophic to eutrophic environments (Herndl 1991) although oligotrophic bacteria are capable of growing fast if conditions are favorable (Peduzzi \& Herndl 1992). Bacterial growth rates in marine snow were found to be similar to those in ambient water even though organic nutrient concentrations are significantly higher in marine snow (Herndl 1992, Müller-Niklas et al. in press). This finding might point to the presence of growth-regulating substances present in the mucoid matrix of marine snow. Based on these considerations, we hypothesized that the expected higher concentrations of acrylic acid in eutrophic waters and in marine snow are responsible for the observed growth pattern of the bacterioplankton under eutrophic conditions.

\section{MATERIAL AND METHODS}

Water samples were collected in the Northern Adriatic Sea, ca $1.5 \mathrm{~km}$ off the Center for Marine Research (Institute 'Ruder Boskovic', Rovinj, Croatia) and during a lagrangian study along $44^{\circ} 45^{\prime} \mathrm{N}$ in the central Northern Adriatic in June 1992. Water was collected with acid-rinsed $(0.1 \mathrm{~N} \mathrm{HCl})$ Niskin bottles from about 2 to $5 \mathrm{~m}$ depth and used for experiments within $1 \mathrm{~h}$ at the Center for Marine Research or on board RV 'Vila Velebita' (during the lagrangian study). Additional experiments were performed at the Department of Marine Biology of the University of Vienna; prefiltered water ( $65 \mu \mathrm{m}$ mesh size) used for these incubation experiments was transported in $10 \mathrm{l}$ carboys at near in situ temperature. For experiments performed in Vienna, the water was used within $2 \mathrm{~d}$ of sampling.

Long-term incubations. Seawater amended with different concentrations of acrylic acid was incubated for 2 to $3 \mathrm{~d}$ at $20^{\circ} \mathrm{C}$ in the dark. Either unfiltered or $0.8 \mu \mathrm{m}$ filtered (Nuclepore polycarbonate filters) seawater in precombusted $\left(450^{\circ} \mathrm{C}\right.$ for $\left.4.5 \mathrm{~h}\right) 1 \mathrm{l}$ Erlenmeyer flasks was used for the incubation experiments. Acrylic acid (Sigma Chemicals) was added to the desired concentrations. One flask per experiment without acrylic acid addition served as control. Thirty $\mathrm{ml}$ subsamples were withdrawn from the flasks at regular time intervals and bacterial density and activity determined as described below. In seawater amended with high acrylic acid concentrations the $\mathrm{pH}$ dropped from ca 8 to 2.5 lat $100 \mathrm{mM}$ acrylic acid conc.). To determine only the potential inhibitory effects of acrylic acid and to exclude the effect of $\mathrm{pH}$ deviations, we performed experiments where one flask was spiked with $10 \mathrm{mM}$ acrylic acid (final conc., $\mathrm{pH}=3.5$ ), a second flask was spiked with the same amount of acrylic acid but, before addition, the acrylic acid was neutralized with $\mathrm{NaOH}$ thereby preventing $\mathrm{pH}$ deviations and a third flask was spiked with $\mathrm{HCl}$ so that the final $\mathrm{pH}$ was the same as in the flask amended with acrylic acid only $(\mathrm{pH}=3.5)_{i}$ an additional flask without any addition served as control. After $2 \mathrm{~h}, 30 \mathrm{ml}$ subsamples were withdrawn and bacterial density and activity determined.

Short-term incubations. Seawater spiked with different concentrations of acrylic acid was incubated $\left(20^{\circ} \mathrm{C}\right.$ in the dark) for $20 \mathrm{~min}$ to investigate potential polymerization effects of acrylic acid since rapid polymerization could have biased our long-term experi- 
ments. For this experiment, $1 \mathrm{l}$ of $0.8 \mu \mathrm{m}$ filtered seawater was incubated in a precombusted Erlenmeyer flask spiked with glucose (Merck, final conc. $10 \mu \mathrm{M}$ ) in order to obtain a fast growing bacterial community. From this culture, $30 \mathrm{ml}$ subsamples were taken and amended with $0.01,0.1,1,10$ and $100 \mathrm{mM}$ acrylic acid (final conc.) and both $\left[{ }^{3} \mathrm{H}\right]$-thymidine and $\left[{ }^{14} \mathrm{C}\right]$-leucine were added to estimate potential short-term effects of acrylic acid on bacterial metabolism. Again 1 flask without addition of acrylic acid served as control.

We chose the acrylic acid concentrations for the experiments according to reported natural DMS concentrations [a few nmol $1^{-1}$ in the central and eastern North Pacific (Bates et al. 1987b), ca $40 \mathrm{nM}$ in the Peru upwelling area (Andreae 1985); $290 \mathrm{nM}$ in Antarctic coastal waters during a Phaeocystis pouchetii bloom (Gibson et al. 1990)] and then raising the concentration stepwise ( 1 order of magnitude at a time) to the concentration used in an earlier study (Sieburth 1960).

Enumeration of bacterial density. Bacterial density was determined by epifluorescence microscopy using the direct counting method with acridine orange staining as described by Hobbie et al. (1977). A $5 \mathrm{ml}$ subsample from each flask was withdrawn and fixed with $0.5 \mathrm{ml}$ conc. $0.2 \mu \mathrm{m}$ filtered formalin. A few drops of $0.2 \mu \mathrm{m}$ prefiltered acridine orange solution were added to the fixed sample and allowed to stain for 2 min. Thereafter the stained sample was filtered onto a black $0.2 \mu \mathrm{m}$ pore size polycarbonate filter (Millipore GTBP, $25 \mathrm{~mm}$ diameter) with a suction pressure of $200 \mathrm{mb}$. The filter was placed on a slide, embedded in paraffin oil and covered with a coverglass. Bacterial density was determined with a Leitz Laborlux microscope with a $100 \times$ Fluotar objective and Ploemopak epifluorescence unit. The working field was adjusted with a diaphragm in a way that 15 to 25 fluorescent particles were counted per working field, and a total of 30 fields were counted per sample; the diameter of the working field was determined by an ocular micrometer. Bacterial density was converted into carbon equivalents using the factor $20 \mathrm{fg} \mathrm{C} \operatorname{cell}^{-1}$ (Lee \& Fuhrman 1987).

Bacterial volume. The biovolume of bacterial cells was determined with an epifluorescence microscope to which an image analyzing system (Jandels Java) was attached. In order to obtain a better image of the bacterial cells DAPI staining was used (Porter \& Feig 1980). Two $\mathrm{ml}$ from each sample was withdrawn and fixed with $0.2 \mathrm{ml}$ concentrated prefiltered $(0.2 \mu \mathrm{m})$ formalin and stained with the DAPI solution for at least 15 min. After staining, the sample was filtered onto a black $0.2 \mu \mathrm{m}$ polycarbonate filter and placed on a slide. Bacterial images from 9 working fields (each covering an area of $1270.9 \mu^{2}$ ) were counted and measured by the image analyzing system. Using the procedure described by Puskaric (in press) the average biovolume as well as the frequency distribution of the volume of the bacterial community was determined.

Leucine and thymidine incorporation into bacteria. $\left[{ }^{3} \mathrm{H}\right]$-leucine (Amersham, specific activity $120 \mathrm{Ci} \mathrm{mmol}^{-1}$, $10 \mathrm{nM}$ final conc.) incorporation into ice-cold trichloroacetic acid (TCA) precipitate was used to estimate bacterial biomass production (Simon \& Azam 1989) as well as $\left[{ }^{3} \mathrm{H}\right]$-thymidine (Amersham, specific activity $85 \mathrm{Ci} \mathrm{mmol}{ }^{-1}, 10 \mathrm{nM}$ final conc.) incorporation into DNA to estimate cell production (Fuhrman \& Azam 1982). Three replicates and 2 formalin-killed blanks (each $5 \mathrm{ml}$ ) were incubated in gamma-radiated tubes (Falcon, Inc.) at $20^{\circ} \mathrm{C}$ in the dark. The blanks were fixed with $0.5 \mathrm{ml}$ concentrated prefiltered formalin. Occasionally the dual labeling technique was applied (Kirchman \& Hoch 1988, Chin-Leo \& Kirchman 1990) using $\left[{ }^{14} \mathrm{C}\right]$-leucine (Amersham, specific activity $319 \mathrm{mCi} \mathrm{mmol}^{-1}, 10 \mathrm{nM}$ final conc.) together with $\left[{ }^{3} \mathrm{H}\right]$-thymidine and incubating for $30 \mathrm{~min}$. The incubation was terminated by fixing the replicates with formalin ( $4 \% \mathrm{v} / \mathrm{v}$ final conc.) and all samples were filtered onto $0.45 \mu \mathrm{m}$ pore size cellulose membrane filters (Millipore HA, $25 \mathrm{~mm}$ diameter) and rinsed with $10 \mathrm{ml}$ ice-cold $5 \%$ TCA for $10 \mathrm{~min}$. The filters were placed into scintillation vials (polyethylene vials, Packard), dissolved with $1 \mathrm{ml}$ ethyl acetate (RiedelDe-Haen) and after $10 \mathrm{~min}, 8 \mathrm{ml}$ of scintillation cocktail (Insta Gel, Packard) was added and the samples counted after $12 \mathrm{~h}$ in a scintillation counter (TRI CARB, Packard). Quenching was corrected by external standard ratio.

\section{RESULTS}

\section{Long-term incubations}

In long-term incubations (2 to $3 \mathrm{~d}$ ) unfiltered seawater was spiked with different concentrations of acrylic acid ranging from 0 to $400 \mathrm{nM}$. At these concentrations bacterial activity was not significantly retarded (Fig. 1). During the course of incubation, bacterial density increased from $7.9 \times 10^{5}$ cells $\mathrm{ml}^{-1}$ (range:

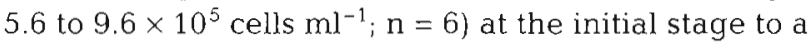
mean value of $15.1 \times 10^{5}$ cells $\mathrm{ml}^{-1}$ (range: 12.7 to $16.2 \times 10^{5}$ cells $\mathrm{ml}^{-1}, \mathrm{n}=6$ ) within $38 \mathrm{~h}$ regardless of the acrylic acid concentrations added (up to $400 \mathrm{nM}$ ). Similarly, bacterial production increased from $1.3 \mu \mathrm{g} \mathrm{C}$ $\mathrm{l}^{-1} \mathrm{~d}^{-1}$ (range: 1.2 to $1.4 \mu \mathrm{g} \mathrm{C}^{-1} \mathrm{~d}^{-1}, \mathrm{n}=6$ ) during the initial phase of the incubation to a mean of $30.6 \mu \mathrm{g} \mathrm{C}$ $\mathrm{l}^{-1} \mathrm{~d}^{-1}$ (range: 27.1 to $32.2 \mu \mathrm{g} \mathrm{C}^{-1} \mathrm{~d}^{-1}, \mathrm{n}=6$ ) and bacterial growth rate from $0.08 \mathrm{~d}^{-1}$ (range: 0.07 to 0.1 ) to 


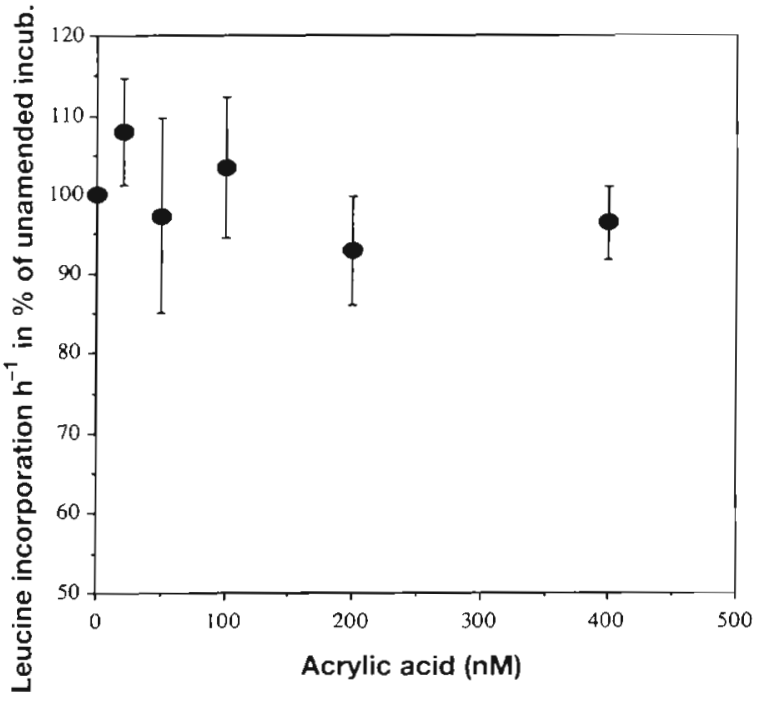

Fig. 1. Leucine incorporation $\mathrm{h}^{-1}$ in bacteria in raw seawater (given as \% bacterial incorporation in unamended flasks) at acrylic acid concentrations ranging from 0 to $400 \mathrm{nM}$ (mean $\pm \mathrm{SD}$ of 7 replicate measurements are presented). Flasks were sampled over a $38 \mathrm{~h}$ period at 4 to $8 \mathrm{~h}$ intervals

$1.03 \mathrm{~d}^{-1}$ (range: 0.84 to 1.26 ) after $38 \mathrm{~h}$. As for bacterial production, bacterial growth rates also did not differ significantly among different acrylic acid concentrations (Wilcoxon, $p>0.2$, in all cases). A second experiment with unfiltered seawater was performed over $46 \mathrm{~h}$ with higher acrylic acid concentrations than in the former experiment $(0,1,2,4,8,16 \mu \mathrm{M})$. Despite the up to 40 times higher acrylic acid concentrations used in this experiment, again no significant differences were detectable among the different treatments (Wilcoxon, $\mathrm{p}>0.2$ ).

In subsequent experiments, $0.8 \mu \mathrm{m}$ filtered seawater was used. This seawater was amended with varying concentrations of acrylic acid ranging from 0 to $100 \mathrm{mM}$ and incubated for 24 to $110 \mathrm{~h}$ (Fig. 2). Bacterial incorporation of leucine and thymidine was significantly reduced at acrylic acid concentrations $>10 \mu \mathrm{M}$ (Wilcoxon, $\mathrm{p}<0.1$, for all incorporation rates at acrylic acid concentrations $>10 \mu \mathrm{M}$ ) and undetectable at 10 and $100 \mathrm{mM}$ concentrations of acrylic acid (Fig. 2). Both leucine and thymidine incorporations exhibited identical trends (Fig. 2). Neither bacterial density nor volume changed among different treatments (Wilcoxon, $p>0.2$ for both density and volume).

To determine whether the observed inhibitory effect was due to acrylic acid or to the associated low $\mathrm{pH}$ values (as shown in Fig. 2), incubation experiments with $10 \mathrm{mM}$ concentrations of acrylic acid without and with adjusted $\mathrm{pH}(\mathrm{pH}=8$ ) were performed. Acrylic acid concentrations of $10 \mathrm{mM}$ with the $\mathrm{pH}$ adjusted caused a decline in bacterial metabolism to ca $42 \%$ of the original metabolic rate in untreated seawater
Table 1 . Influence of $\mathrm{pH}$ and acrylic acid concentrations on leucine (Leu) and thymidine ( $T d R$ ) incorporation $\mathrm{h}^{-1}$ into bacteria given as \% bacterial incorporation in unamended $0.8 \mu \mathrm{m}$ filtered seawater; measurements were performed in dupljcates; mean and range are given

\begin{tabular}{|c|c|c|c|}
\hline $\begin{array}{l}\text { Acrylic acid conc. } \\
\text { (mM) }\end{array}$ & $\mathrm{pH}$ & \multicolumn{2}{|c|}{$\begin{array}{l}\text { Leu inc } \quad \text { TdR inc. } \\
\text { (in \% of unamended seawater }\end{array}$} \\
\hline 0 & 3.5 & $\begin{array}{c}3.2 \\
(1.5-4.9)\end{array}$ & $\begin{array}{c}2.9 \\
(1.4-4.4)\end{array}$ \\
\hline 10 & 3.5 & $\begin{array}{c}1.9 \\
(0.8-2.9)\end{array}$ & $\begin{array}{c}2.2 \\
(0.7-3.6)\end{array}$ \\
\hline 10 & 8.0 & $\begin{array}{c}42.3 \\
(33.0-51.6)\end{array}$ & $\begin{array}{c}42.2 \\
(32.6-51.7)\end{array}$ \\
\hline
\end{tabular}

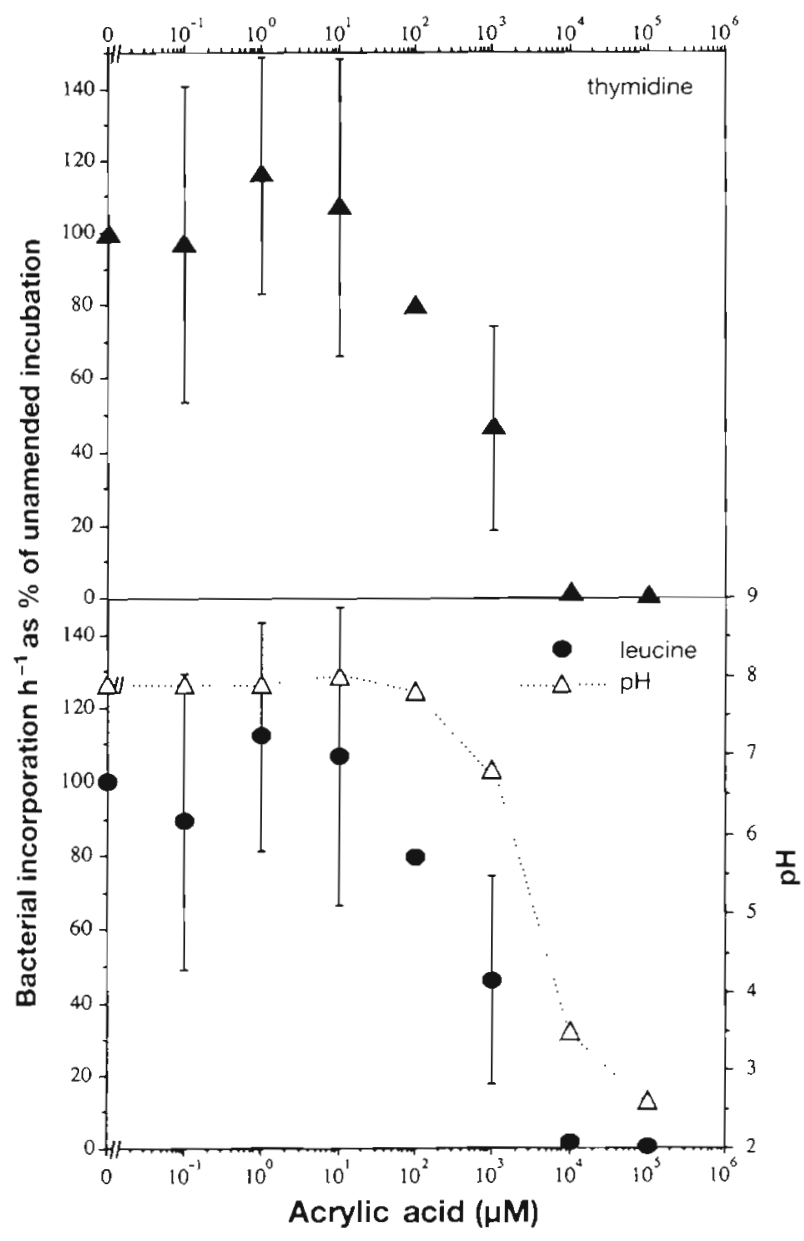

Fig. 2. Thymidine (upper panel) and leucine (lower panel) incorporation $\mathrm{h}^{-1}$ in bacteria in $0.8 \mu \mathrm{m}$ filtered seawater at acrylic acid concentrations of up to $100 \mathrm{mM}$; the $\mathrm{pH}$ deviated from 8.1 in the unamended flask to 2.5 in the flask arnended with $100 \mathrm{mM}$ acrylic acid (mean $\pm \mathrm{SD}$ of 3 to 14 replicate measurements are presented); values are given in \% of unamended incubations in order to facilitate comparison among experiments. Flasks were sampled over a period ranging from 24 to 118 h at 4 to $24 \mathrm{~h}$ intervals 


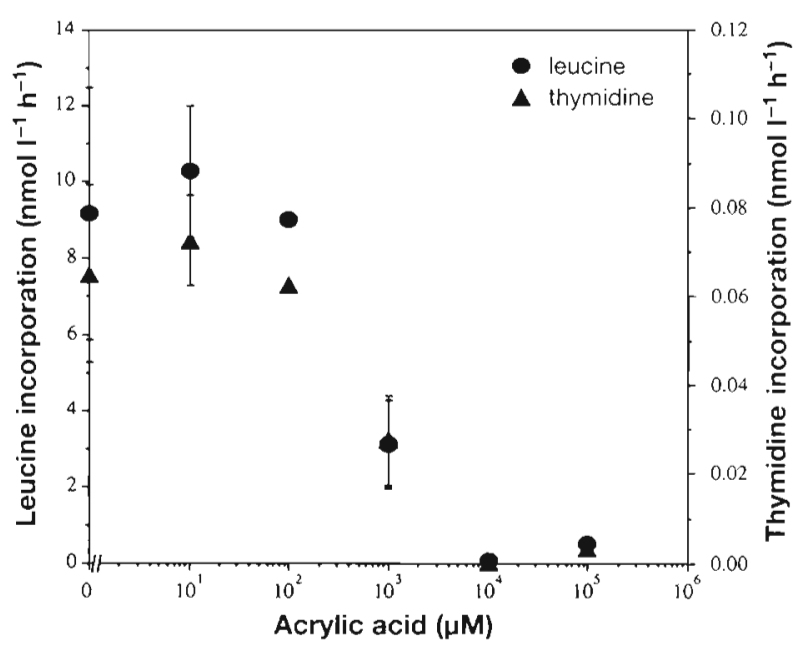

Fig. 3. Short-term response of bacteria to acrylic acid addition. Acrylic acid at varying concentrations and both thymidine and leucine were added. Symbols represent mean \pm SD of 1 to 3 replicate measurements

(Table 1). A pH of 3.5 caused a drastic reduction in bacterial activity. In both leucine and thymidine incorporations the $10 \mathrm{mM}$ acrylic acid addition led to a further reduction in bacterial metabolism by 60 and $75 \%$, respectively (Table 1 ).

\section{Short-term incubations}

In order to evaluate possible short-term effects of acrylic acid on bacterial metabolism, 20 min incubations were performed with $\left[{ }^{14} \mathrm{C}\right]$-leucine and $\left[{ }^{3} \mathrm{H}\right]$ thymidine added to seawater cultures amended with various concentrations of acrylic acid. In contrast to long-term incubations in which a significant reduction in bacterial metabolism was detectable at acrylic acid concentrations $>10 \mu \mathrm{M}$, in these short-term incubations a reduction was only observed at concentrations $>100 \mu \mathrm{M}$ (Fig. 3).

\section{DISCUSSION}

In this study we used seawater cultures and natural bacterial consortia. Incubation of bacterioplankton over a prolonged period of time under such confined conditions may potentially alter the community structure. Our incubation experiments, however, did not show significant alterations in the sensitivity of bacterial growth to acrylic acid over time. Thus we are confident that our data reflect the actual response of natural bacterial communities to acrylic acid concentrations.

The minimum concentration of acrylic acid reducing bacterial metabolism significantly was found to be between 10 and $100 \mu \mathrm{M}$ (Fig. 2) which is about 1 order of magnitude lower than the minimum concentration causing growth reduction in the study of Sieburth (1960). At an acrylic acid concentration of $1 \mathrm{mM}$ bacterial metabolism was reduced by about 50\% (Fig. 2). DMS concentrations in seawater are in the nM range (Andreae \& Barnard 1984, Turner et al. 1988, Cooper \& Matrai 1989, Gibson et al. 1990). Nanomolar concentrations of acrylic acid, however, did not produce any significant reduction in bacterial metabolism (Fig. 1) although acrylic acid has been frequently cited as a potential inhibitor of bacterial growth (Guillard \& Hellebust 1971, Davidson \& Marchant 1987, Wakeham \& Dacey 1989). None of these studies specifically investigated the influence of acrylic acid on bacterial metabolism but refer to the work of Sieburth (1960, 1961) who used, however, plating techniques and acrylic acid concentrations ranging from the $\mu \mathrm{M}$ to the $m M$ range. The question emerges now whether or not such high concentrations do occur in the water column. Commonly reported concentrations of DMS are $<10 \mathrm{nM}$ for oligotrophic and between 10 and $50 \mathrm{nM}$ for eutrophic waters (Andreae \& Raemdonck 1983, Holligan et al. 1987, Cooper \& Matrai 1989, Leck et al. 1990); only under specific bloom conditions can DMS concentrations rise to $290 \mathrm{nM}$ (Gibson et al. 1990). Assuming that these concentrations of DMS are also representative for acrylic acid in marine waters we may conclude that bacterioplankton is hardly affected by acrylic acid in the pelagic environment.

Phytoplankton can aggregate, however, either forming colonies such as Phaeocystis pouchetii or becoming embedded in mucoid material like marine snow (Alldredge \& Silver 1988, Kaltenböck \& Herndl 1992). Under such conditions phytoplankton biomass may be enriched in marine snow by a factor of up to 1000 as compared to ambient water. Assuming similar enrichment factors for acrylic acid, concentrations of approximately 10 to $50 \mu \mathrm{M}$ could occur in marine snow. In fact, Davidson (1985) found acrylic acid concentrations in cultures of $P$. pouchetii of up to $70 \mu \mathrm{M}$, which is close to our estimated acrylic acid concentration in marine snow. At these concentrations acrylic acid would be sufficient to retard bacterial metabolism as shown in this paper (Fig. 2). It has to be considered, however, that there are large variations in the production rates of DMSP among marine phytoplankton species (Keller et al. 1989a). Autotrophic flagellates are known to release copious amounts of DMSP (Keller et al. 1989a) and they are usually also a prominent autotrophic component in marine snow in the Northern Adriatic Sea (Herndl 1988, Revelante \& Gilmartin 1991). Low chlorophyll a: phaeopigment ratios in marine snow indicate the predominance of senescent phytoplankton cells (Herndl 1992); such senescent cells have been shown 
to release elevated amounts of DMSP (Nguyen et al. 1988, Turner et al. 1988). Low growth rates have been observed for both bacteria and phytoplankton embedded in marine snow although nutrient concentrations in marine snow are orders of magnitude higher than in the ambient water (Kaltenböck \& Herndl 1992, MüllerNiklas et al. in press). This phenomenon of low growth rates of microorganisms inhabiting marine snow despite the high concentrations of potentially available nutrients is currently under investigation. Here particular attention is being paid to the possible role of acrylic acid in regulating microbial growth rates in this microenvironment (D. M. Slezak unpubl, data)

Although we have shown that acrylic acid does not inhibit bacterial metabolism at concentrations usually detected in situ, it might well be that acrylic acid retards bacterial growth not only in environments like marine snow but also on a much smaller spatial scale - the phycosphere (Bell et al. 1974). Considering that some phytoplankton species produce large amounts of DMSP (Keller et al. 1989a), high concentrations of DMSP could occur around single phytoplankton cells before being cleaved into DMS and acrylic acid by bacteria. Kiene (1990) isolated 2 strains of bacteria from coastal waters capable of growing on acrylic acid as the sole carbon source. The extent to which this occurs under in situ conditions remains to be investigated.

Based on the concentrations of DMS, nanomolar levels of acrylic acid might be expected to occur in the euphotic zone while significant reduction in bacterial growth as determined in this study was detectable only at concentrations $>10 \mu \mathrm{M}_{i}$ at concentrations of $1 \mathrm{mM}$ bacterial metabolism was reduced by $50 \%$. Concentrations $>10 \mu \mathrm{M}$ can only be expected to occur in aggregated phytoplankton such as marine snow. Methodological problems so far prevented measurements of acrylic acid in natural marine waters as well as in special environments like marine snow; nevertheless such data are urgently needed to conclusively evaluate the ecological role of acrylic acid in the sea.

Acknowledgements. We thank our colleagues at the Dept of Marine Biology at the Institute of Zoology as well as the staff of the Institute 'Ruder Boskovic', Center for Marine Research at Rovinj, Croatia. This study was supported by the Austrian Science Foundation (FWF\# 8608 and 9388 to G.J.H.). The work is part of the fulfilment of the requirements towards a M.Sc degree at the University of Vienna by D.M.S.

\section{LITERATURE CITED}

Alldredge, A. L., Silver, M. W. (1988). Characteristics, dynamics and significance of marine snow. Prog. Oceanogr. 20: $41-82$
Andreae, M. O. (1985). Dimethylsulfide in the water column and the sediment porewaters of the Peru upwelling area. Limnol. Oceanogr. 30: 1208-1218

Andreae, M. O. (1990). Ocean-atmosphere interactions in the global biogeochemical sulfur cycle. Mar. Chem. 30: 1-29

Andreae, M. O., Barnard, W. R. (1984). The marine chemistry of dimethylsulfide. Mar. Chem. 14: 267-279

Andreae, M. O., Raemdonck, H. (1983). Dimethyl sulfide in the surface ocean and the marine atmosphere: a global view. Science 221: 744-747

Barnard, W. R., Andreae, M. O., Watkins, W. E., Bingemer, H., Georgii, H.-W. (1982). The flux of dimethylsulfide from the oceans to the atmosphere. J. geophys. Res. $87 \mathrm{C} 11$ : $8787-8793$

Bates, T. S., Charlson, R. J., Gammon, R. H. (1987a). Evidence for the climatic role of marine biogenic sulphur. Nature 329: 319-321

Bates, T. S., Cline, J. D., Gammon, H., Kelly-Hansen, S. R. (1987b). Regional and seasonal variations in the flux of oceanic dimethylsulfide to the atmosphere. J geophys. Res. 92 C3: $2930-2938$

Bell, W. H., Lang, J. M., Mitchell, R. (1974). Selective stimulation of marine bacteria by algal extracellular products. Limnol. Oceanogr. 25: 1007-1020

Brimblecombe, P., Shooter, D. (1986). Photo-oxidation of dimethylsulphide in aqueous solution. Mar. Chem. 19: $343-353$

Cantoni, G. L., Anderson, D. G. (1956). Enzymatic cleavage of dimethylpropiothetin by Polysiphonia lanosa. J biol. Chem. 222: 171-177

Charlson, R. J., Lovelock, J. E., Andreae, M. O., Warren, S. G. (1987). Oceanic phytoplankton, atmospheric sulphur, cloud albedo and climate. Nature 326: 655-661

Charlson, R. J., Rodhe, H. (1982). Factors controlling the acidity of natural rainwater. Nature 295: 683-685

Chin-Leo, G., Kirchman, D. L. (1990). Unbalanced growth in natural assemblages of marine bacterioplankton. Mar. Ecol. Prog. Ser. 63: 1-8

Cho, B. C., Azam, F. (1990). Biogeochemical significance of bacterial biomass in the ocean's euphotic zone. Mar. Ecol. Prog. Ser. 63: 253-259

Cooper, W. J., Matrai, P. A. (1989). Distribution of dimethyl sulfide in the oceans. In: Saltzman, E. S., Cooper, W. J. (eds.) Biogenic sulfur in the environment. American Chemical Society, Washington, DC, p. 140-151

Davidson, A. T (1985). Aspects of the biology of Phaeocystis pouchetii (Prymnesiophyceae). University of Tasmania, Tasmania

Davidson, A. T., Marchant, H. J. (1987). Binding of manganese by Antarctic Phaeocystis pouchetii and the role of bacteria in its release. Mar. Biol. 95: 481-487

Dickson, D. M. J., Kirst, G. O. (1986). The role of $\beta$-dimethylsulphoniopropionate, glycine betaine and homarine in the osmoacclimation of Platymonas subcordiformis. Planta 167: $536-543$

Dortch, Q., Packard, T T (1989). Differences in biomass structure between oligotrophic and eutrophic marne ecosystems. Deep Sea Res. 36: 223-240

Erickson, D. J. I., Ghan, S. J., Penner, J. E. (1990). Global ocean-to-atmosphere dimethyl sulfide flux. J. geophys. Res. 95: 7543-7552

Fogelquist, E. (1991). Dimethylsulphide (DMS) in the Weddell Sea surface and bottom water. Mar. Chem. 35: 169-177

Fuhrman, J. A., Azam, F. (1982). Thymidine incorporation as a measure of heterotrophic bacterioplankton production in marine surface waters: evaluation and field results. Mar. Biol. 66: 109-120 
Fuhrman, J. A., Sleeter, T. D., Carlson, C. A., Proctor, L. M. (1989). Dominance of bacterial biomass in the Sargasso Sea and its ecological implications. Mar. Ecol. Prog. Ser. 57: 207-217

Gibson, J. A. E., Garrick, R. C., Burton, H. R., McTaggart, A. R. (1990). Dimethylsulfide and the alga Phaeocystis pouchetii in Antarctic coastal waters. Mar. Biol. 104: 339-346

Guillard, R. R. L., Hellebust, J. A. (1971). Growth and the production of extracellular substances by two strains of Phaeocystis pouchetii. J. Phycol. 7: 330-338

Herndl, G. J. (1988). Ecology of amorphous aggregations (marine snow) in the Northern Adriatic Sea. II. Microbial density and activity in marine snow and its implication to overall pelagic processes. Mar. Ecol. Prog. Ser, 48: $265-275$

Herndl, G. J. (1991). Microbial biomass dynamics along a trophic gradient at the Atlantic Barrier Reef off Belize (Central America). P.S.Z.N. I: Mar. Ecol. 12: 41-51

Herndl, G. J. (1992). Marine snow in the northern Adriatic Sea: possible causes and consequences for a shallow ecosystem. Mar. Microb. Food Webs 6: 149-172

Hobbie, J. E., Daley, R. J., Jasper, S. (1977). Use of Nuclepore filters for counting bacteria by epifluorescence microscopy. Appl environ. Microbiol. 33: 1225-1228

Holligan, P. M., Turner, S. M., Liss, P. S. (1987). Measurements of dimethyl sulphide in frontal regions. Cont. Shelf Res. 7: 213-224

Kaltenböck, E., Herndl, G. J. (1992). Ecology of amorphous aggregations (marine snow) in the Northern Adriatic Sea: IV. Dissolved nutrients and the autotrophic community associated with marine snow. Mar. Ecol. Prog. Ser. 87: $147-159$

Keller, M. D., Bellows, W. K., Guillard, R. R. L. (1989a), Dimethyl sulfide production in marine phytoplankton. In: Saltzman, E. S., Cooper, W. J. (eds.) Biogenic sulfur in the environment. American Chemical Society, Washington, DC, p. 167-182

Keller, M. D., Bellows, W. K., Guillard, R. R. L. (1989b). Dimethylsulfide production and marine phytoplankton: an additional impact of unusual blooms. In: Cosper, E. M., Bricelj, V. M., Carpenter, E. J. (eds.) Novel phytoplankton blooms. Springer, Heidelberg, p. 101-115

Kiene, R. P. (1990). Dimethyl sulfide production from dimethylsulfoniopropionate in coastal seawater samples and bacterial cultures. Appl. environ. Microbiol. 56: 3292-3297

Kiene, R. P., Bates, T. S. (1990). Biological removal of dimethyl sulphide from sea water. Nature 345: 702-705

Kirchman, D. L., Hoch, M. P. (1988). Bacterial production in the Delaware Bay estuary estimated from thymidine and leucine incorporation rates. Mar. Ecol. Prog. Ser. 45: $169-178$

This article was submitted to the editor
Leck, C., Larsson, U., Bagander, L. E., Johansson, S., Hajdu, S. (1990). Dimethyl sulfide in the Baltic Sea: annual variability in relation to biological activity. J. geophys. Res. 95 C3: $3353-3363$

Lee, S., Fuhrman, J. A. (1987). Relationships between biovolume and biomass of naturally derived marine bacterioplankton. Appl environ. Microbiol. 53: 1298-1303

Malin, G., Turner, S. M., Liss, P. S. (1992). Sulfur: the plankton/climate connection. J. Phycol. 28: 590-597

Müller-Niklas, G., Schuster, S., Kaltenböck, E., Herndl, G. J. (in press). Organic content and bacterial metabolism in amorphous aggregations of the northern Adriatic Sea. Limnol. Oceanogr.

Nguyen, B. C., Belviso, S., Mihalopoulos, N. (1988). Dimethyl sulfide production during natural phytoplanktonic blooms. Mar. Chem. 24: 133-141

Peduzzi, P., Herndl, G. J. (1992). Zooplankton activity fueling the microbial loop: differential growth response of bacteria from oligo- and eutrophic waters. Limnol. Oceanogr. 37: 1087-1092

Porter, K. G., Feig, Y. S (1980). The use of DAPI for identifying and counting aquatic microflora. Limnol. Oceanogr. 25: $943-948$

Puskaric, S. (in press). Density and biomass determination of heterotrophic bacteria and cyanobacteria by image analysis. Helgoländer Meeresunters.

Revelante, N., Gilmartin, M. (1991). The phytoplankton composition and population enrichment in gelatinous 'macroaggregates' in the Northern Adriatic during the summer of 1989. J. exp. mar. Biol. Ecol. 146: 217-233

Sieburth, J. M. (1960). Acrylic acid, an 'antibiotic' principle in Phaeocystis blooms in Antarctic waters. Science 132: 676-677

Sieburth, J. M. (1961). Antibiotic properties of acrylic acid, a factor in the gastrointestinal antibiosis of polar marine animals. J. Bacteriol. 82: 72-79

Simon, M., Azam, F. (1989). Protein content and protein synthesis rates of planktonic marine bacteria. Mar. Ecol. Prog. Ser. 51: 201-213

Turner, S. M., Malin, G., Liss, P. S. (1988). The seasonal variation of dimethyl sulfide and dimethylsulfoniopropionate concentrations in nearshore waters. Limnol. Oceanogr. 33(3): $364-375$

Vairavamurthy, A., Andreae, M. O., Iverson, R. L. (1985) Biosynthesis of dimethylsulfide and dimethylpropiothetin by Hymenomonas carterae in relation to sulfur source. Limnol. Oceanogr. 30(1): 59-70

Wakeham, S. G., Dacey, J. W. H. (1989). Biogeochemical cycling of dimethylsulfide in marine environments. In: Saltzman, E. S., Cooper, W. J. (eds.) Biogenic sulfur in the environment. American Chemical Society, Washington, DC, p. $152-166$

Manuscript first received: July 13, 1993

Revised version accepted: November 19, 1993 